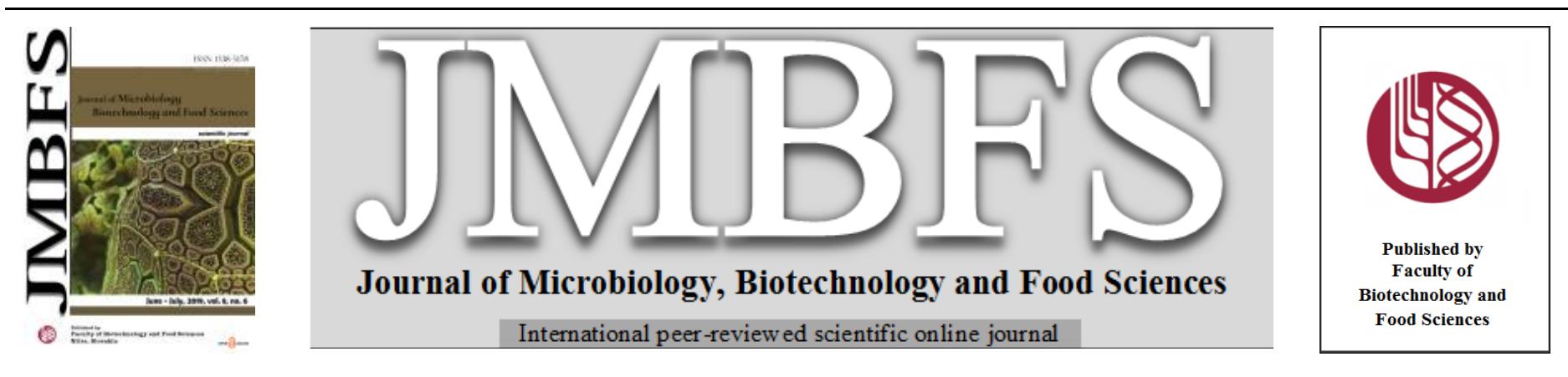

\title{
CLONING, PURIFICATION AND CHARACTERIZATION OF A NOVEL RECOMBINANT TREHALOSE SYNTHASE (TreS) FROM Acidiplasma sp. MBA-1
}

\author{
Md. Azmain Al Faik ${ }^{1}$, Rana Das ${ }^{2}$, Jiang Bo ${ }^{* 1}$, Wanmeng Mu ${ }^{1}$, Hinawi Hassanin ${ }^{l}$
}

\section{$\operatorname{Address}(e s)$ :}

${ }^{1}$ Jiangnan University, State Key Laboratory of Food Science \& Technology, Synergetic Innovation Centre of Food Safety \& Nutrition, Lihu Avenue 1800 , Wuxi214122, China, Phone: +86-510-859-13623.

${ }^{2}$ State University of Bangladesh, Department of Food Engineering \& Technology, Satmasjid Road 77, Dhaka-1209, Bangladesh, Phone: 09613-782338.

*Corresponding author: bjiang@jiangnan.edu.cn

doi: 10.15414/jmbfs.2019.8.6.1298-1302

ARTICLE INFO

Received 10. 8. 2018

Revised 3. 2. 2019

Accepted 4. 2. 2019

Published 1. 6. 2019

Regular article

OPEN $\partial_{\text {ACCESS }}$

\begin{abstract}
Trehalose, a nonreducing disaccharide, can be commercially produced using maltose from microorganisms. An intramolecular transglycosylase enzyme called trehalose synthase (TreS) can catalyze the conversion of maltose to trehalose in a single step reaction. Hence, in our study a novel gene TreS encoded with 562 amino acids was cloned from Acidiplasma sp. MBA-1 and expressed into $E$. coli BL21 (DE). HPLC results suggested that it could catalyze the conversion between maltose and trehalose in one step. The conversion of trehalose from maltose was about $43.62 \%$ in our study. At the same time, TreS produced about $23.85 \%$ glucose as a byproduct after $10 \mathrm{~h}$ of incubation. SDS page results showed that the purified recombinant enzyme has a molecular weight of $65.9 \mathrm{kDa}$. The recombinant TreS showed its optimal activity at $40^{\circ} \mathrm{C}$ and its optimum $\mathrm{pH}$ was 6.5 . Our study shows that the enzyme was not thermostable and its activity was increased by $1 \mathrm{mM}$ EDTA, $\mathrm{Mn}^{2+}$ and $\mathrm{Li}^{+}$whereas $\mathrm{Cu}^{2+}$ and $\mathrm{Ni}^{2+}$ strongly inhibited the enzyme activity.
\end{abstract}

Keywords: Trehalose, Trehalose synthase, Acidiplasma sp. MBA-1, Escherichia coli, purification

\section{INTRODUCTION}

Trehalose, also known as $\alpha$-D-glucopyranosyl, $\alpha$-D-glucopyranoside, is a disaccharide molecule made up of two glucose molecules linked with a 1,1 glycosidic linkage. It is mostly found in a variety of organisms i.e., bacteria, fungi, invertebrates etc (Himei 2008). Although trehalose was well known for carbon and energy source of plants and animals for years, the researches in the last two decades showed that trehalose is a multifunctional molecule as well. It is found in cell wall glycolipid as a structural component )Arguelles, 2000; Richards, 2002). Trehalose is very stable under hot and acidic conditions. Mizumoto et al (2004) showed that trehalose can be used as a bulk agent due to its stability towards heat and hydrolysis. Moreover, it does not caramelize and undergoes Maillard reactions and it is safe for human consumption and widely accepted by the European regulation system (Richards et al., 2002; Schiraldi, Di Lernia, \& De Rosa, 2002). It can also stabilize enzymes in vegetables )Aga et al.,1988), suppress bitterness and enhance sourness )Oku, 1995(, suppresses foul odor (Kubota, 2005), suppresses oxidation (Himei, 2008) reaction as well. Colaco \& Roser (1995) reported that it can be used as an additive for food preservation. Zdzieblo \& Synowiecki(2006) suggested that trehalose can be used for food processing because of its certain unique properties; mild sweetness, low carcinogenicity, good solubility in water, stability under low $\mathrm{pH}$ conditions, low hygroscopicity, depression of freezing point, high glass transition temperature and ability to protect proteins. Although trehalose is abundant in many microorganisms, it's commercial production for the industries has been a big challenge until several enzyme synthesis systems in microorganisms have been discovered )Lama et al. 1990; Nakada et al.1996; Di Lernia et al. 1998(which opened a new dimension in commercial trehalose production in the industries. Avonce)2006( reported that there are five main enzymatic pathways of trehalose biosynthesis has been identified so far. Two of which are very popular for commercial production of trehalose; MTS-MTH pathway (two novel enzymes maltooligosyl trehalose synthase and maltooligosyl trehalose trehalohydrolase convert maltodextrin into trehalose in a two-step reaction) and TreS pathway )Trehalose synthase isomerizes $\alpha 1-\alpha 4$ bond of maltose to $\alpha 1-\alpha 1$ bond resulting in trehalose(.The later one requires less energy, more simple, fast and costeffective. Acidiplasma sp. MBA-1 is a novel acidophilic, cell wall-less archaeon, excretes a significant amount of trehalose into the culture media. A new gene for trehalose synthase has been identified from Acidiplasma $s p$ MBA-1(GenBank). In this study, we hypothesized that the gene could be expressed into an E. coli expression system and using this enzyme trehalose could be produced commercially. We also aim to purify and characterize the trehalose synthase from Acidiplasma $s p$ MBA-1. To the best of our knowledge, this is the first report on purification and characterization of trehalose synthase (TreS) from this bacterial strain.

\section{MATERIALS AND METHODS}

The column resin for recombinant Acidiplasma sp. MBA-1TreS purification, the chelating Sepharose Fast Flow, was obtained from GE (Uppsala, Sweden). Electrophoresis reagents were purchased from Bio-Rad. Isopropyl- $\beta-D-1$ thiogalactopyranoside (IPTG) and all chemicals for the assay were from SigmaAldrich (St. Louis, MO, USA). Standard trehalose was bought from Sinopharma Ltd., China. The reconstructed plasmid was synthesized by Generay Biotech Co., Ltd. (Shanghai, China).

\section{Gene Cloning and expression of recombinant TreS}

According to information from the NCBI, the whole genome of Acidiplasma sp. MBA-1 was sequenced by Bulaev A.G. in 2015 and was released into the Gen Bank (NCBI) with the accession number KJE50039.1. The target DNA gene (gene locus_tag: TZ01_03000) and the gene encoding the hypothetical protein of RDH (protein ID number WP_048101287.1) was synthesized and cloned into the pET-22b(+) vector with NdeI and XhoI sites and an in-frame fusion His6-tag sequence at the C-terminus was provided in the reconstructed plasmid. The plasmid was named pET-TreS and was transformed into E. coli BL21 (DE) for TreS overexpression. The E. coli BL21 (DE) cells harboring the pET-TreS plasmid were cultured in Luria Bertani medium supplemented with the antibiotic (kanamycin) to a final concentration of $100 \mu \mathrm{g} \mathrm{mL} \mathrm{m}^{-1}$ and incubated at $37{ }^{\circ} \mathrm{C}$. After the culture reached an optical density of $0.6-0.8$ at $600 \mathrm{~nm}$, IPTG was added to the culture to a final concentration of $1 \mathrm{mM}$, and TreS was induced at 28 ${ }^{\circ} \mathrm{C}$ for $6 \mathrm{~h}$.

\section{Purification of recombinant TreS}

The cells were collected by centrifugation at $8,000 \times g$ for 10 minutes and then washed with $50 \mathrm{mM}$ sodium phosphate buffer (PBS) with a $\mathrm{pH}$ of 7.5. The washed cells resuspended in the lysis buffer were disrupted by ultrasonication at 
$4{ }^{\circ} \mathrm{C}$ using a Vibra-Cell 72405 Sonicator (BioBlock Scientific, Illkirch, France). The disrupted cells were removed by centrifugation $(10,000 \times g$ for 30 minutes at $4{ }^{\circ} \mathrm{C}$ ). The collected supernatant (crude enzyme) was loaded onto a chelating Sepharose Fast Flow resin column $(1.0 \times 10.0 \mathrm{~cm})$ charged with $\mathrm{Ni}^{2+}$ and equilibrated with the binding buffer (50 mM PBS, $500 \mathrm{mM} \mathrm{NaCl}, \mathrm{pH} 7.5$ ). Unbounded proteins in the column were removed with the washing buffer (50 $\mathrm{mM}$ PBS buffer, $500 \mathrm{mM} \mathrm{NaCl}, 50 \mathrm{mM}$ imidazole, $\mathrm{pH}$ 7.5). TreS was subsequently eluted with the elution buffer $(50 \mathrm{mM}$ PBS buffer, $500 \mathrm{mM} \mathrm{NaCl}$, $500 \mathrm{mM}$ imidazole, $\mathrm{pH}$ 7.5). The collected pure enzyme was dialyzed for $24 \mathrm{~h}$ at $4{ }^{\circ} \mathrm{C}$ against the dialysis buffer $(50 \mathrm{mM}$ sodium phosphate buffer, $\mathrm{pH} 7.5)$.

\section{Activity assay of TreS}

The activity was determined by measuring the amount of trehalose produced from maltose. The total volume of the standard reaction was $1 \mathrm{ml}$ consisting of $900 \mu 150 \mathrm{mM}$ sodium phosphate $(\mathrm{pH} 6.5)$ as a substrate solution ( $1 \%$ maltose) and $100 \mu \mathrm{l}$ of purified enzyme. The mixture was incubated for $1 \mathrm{~h}$ at $40^{\circ} \mathrm{C}$. After that, the reaction mixture was heated at $100^{\circ} \mathrm{C}$ in boiling water for 10 minutes to stop the reaction.

\section{Carbohydrate Analysis}

Trehalose was detected by High-Performance Liquid Chromatography (HPLC) system equipped with a refractive index detector and an $\mathrm{NH}_{2}$ column (Water Spherisorb ${ }^{\circledR} 5 \mu \mathrm{m}, 46 \times 250 \mathrm{~mm}$ ). The flow rate of the mobile phase was $1 \mathrm{ml} / \mathrm{min}$. The mobile phase consists of $77.5 \%$ acetonitrile, $15 \%$ methanol and $7.5 \% \mathrm{ddH}_{2} \mathrm{O}$

\section{Effect temperature on TreS}

The effects of temperature on the activity of TreS was determined at various temperatures $\left(20-60{ }^{\circ} \mathrm{C}\right)$. To check the stability of the TreS enzyme against temperature, $100 \mu \mathrm{l}$ of purified TreS were preincubated with $50 \mathrm{mM}$ sodium phosphate buffer $(\mathrm{pH} 6.5)$ for $1 \mathrm{~h}$ at different temperature ranging from $20-60{ }^{\circ} \mathrm{C}$. Finally, a standard reaction was carried out at $40{ }^{\circ} \mathrm{C}$ for $1 \mathrm{~h}$ adding $1 \%$ substrate (maltose) into the preincubated purified enzyme. The residual activity was measured by the HPLC system.

\section{Effect of pH on TreS}

The effect of $\mathrm{pH}$ on the activity of TreS was determined at various $\mathrm{pH}(5-8.5)$ using $50 \mathrm{mM}$ sodium phosphate buffer at $40{ }^{\circ} \mathrm{C}$. The standard reaction was carried out for $1 \mathrm{~h}$. The residual activity was measured by the HPLC system.

\section{Effect of Metal Ions and EDTA activity}

The enzyme solution was incubated with various metal ions $\mathrm{Mn}^{2+}, \mathrm{Ni}^{2+}, \mathrm{Cu}^{2+}$ $\mathrm{Mg}^{2+}, \mathrm{Ba}^{2+}, \mathrm{Zn}^{2+}, \mathrm{Al}^{3+}, \mathrm{Fe}^{2+}, \mathrm{Li}^{+}, \mathrm{Co}^{2+}$ and a chelating reagent EDTA at a final concentration of $1 \mathrm{mM}$. The residual activity was measured by the HPLC system. The measured activities were compared to the enzyme activity without the addition of metal ions (control) under the same conditions.

\section{Total protein concentration}

The total protein concentration was measured according to the Bradford method (Bradford, 1976). Bovine serum albumin was used as a standard.

\section{Substrate specificity}

Different sugars have been used as a substrate to check the substrate specificity of the enzyme TreS. We have used Glucose, Lactose, Sucrose, Fructose, Mannose, $\beta$-cyclodextrin, Starch, Cellobiose and Galactose as a substrate. The reaction was carried out at optimum conditions with $1 \%$ maltose as a substrate The relative activity was determined by the HPLC.

\section{Conversion rate}

To determine the conversion rate of the TreS enzyme, a series of standard reactions were carried out using $1 \%$ maltose as a substrate. The standard $1 \mathrm{ml}$ reaction mixture containing $900 \mu$ lsodium phosphate buffers $(50 \mathrm{mM})$ as a substrate solution and $100 \mu \mathrm{l}$ purified enzyme was used. The reaction was carried out at a different time $(0-10 \mathrm{~h})$. The residual activity was measured by the HPLC system.

\section{SDS page}

As described by Laemmli, the subunit molecular weight of recombinant TreS was examined by using the denaturing conditions of sodium dodecyl sulfatepolyacrylamide gel electrophoresis (SDS-PAGE) on a 5\% stacking gel and a 12\% separating gel. Gels were stained with Coomassie Brilliant Blue 250 and destained with an aqueous mixture of $10 \%(\mathrm{v} / \mathrm{v})$ methanol/10\% (v/v) acetic acid

\section{Sequence similarity}

Acidiplasma sp MBA-1 amino acid sequence released from the gene sequence was compared with similar enzymes from other organisms using the NCBI web site tool BLAST and the sequence alignment tool ClustalW2 (http://www.ebi.ac.uk/Tools/clustalw2/index.html).

\section{RESULTS}

\section{Gene Cloning and expression}

The genome of Acidiplasma sp. MBA-1 released in the gene bank with accession number KJE50039.1 was analyzed and the existence of a trehalose synthase with protein ID WP_048101287.1 that convert maltose to trehalose was potentially identified. According to this analysis, the gene was synthesized and the target gene was sub-cloned into pET-22b (+) and named pET-TreS. This construct was transformed into E. coli BL21 (DE3( cells and Acidiplasma sp. MBA-1 trehalose synthase (Tres( overexpression was induced by IPTG. Using the NCBI amino acid sequence of the Acidiplasma sp. MBA-1 showed sequence identities of 89 , 66, 63 and 59\% with Picrophilus torridus [accession number is WP_011176870.1], Bacteriam JKG1 [accession number is WP_029315667.1], Kouleothrix aurantiaca [accession number is KPV52019.1], Myxococcus xanthus [accession number is WP_011553702.1], respectively (Fig.1).

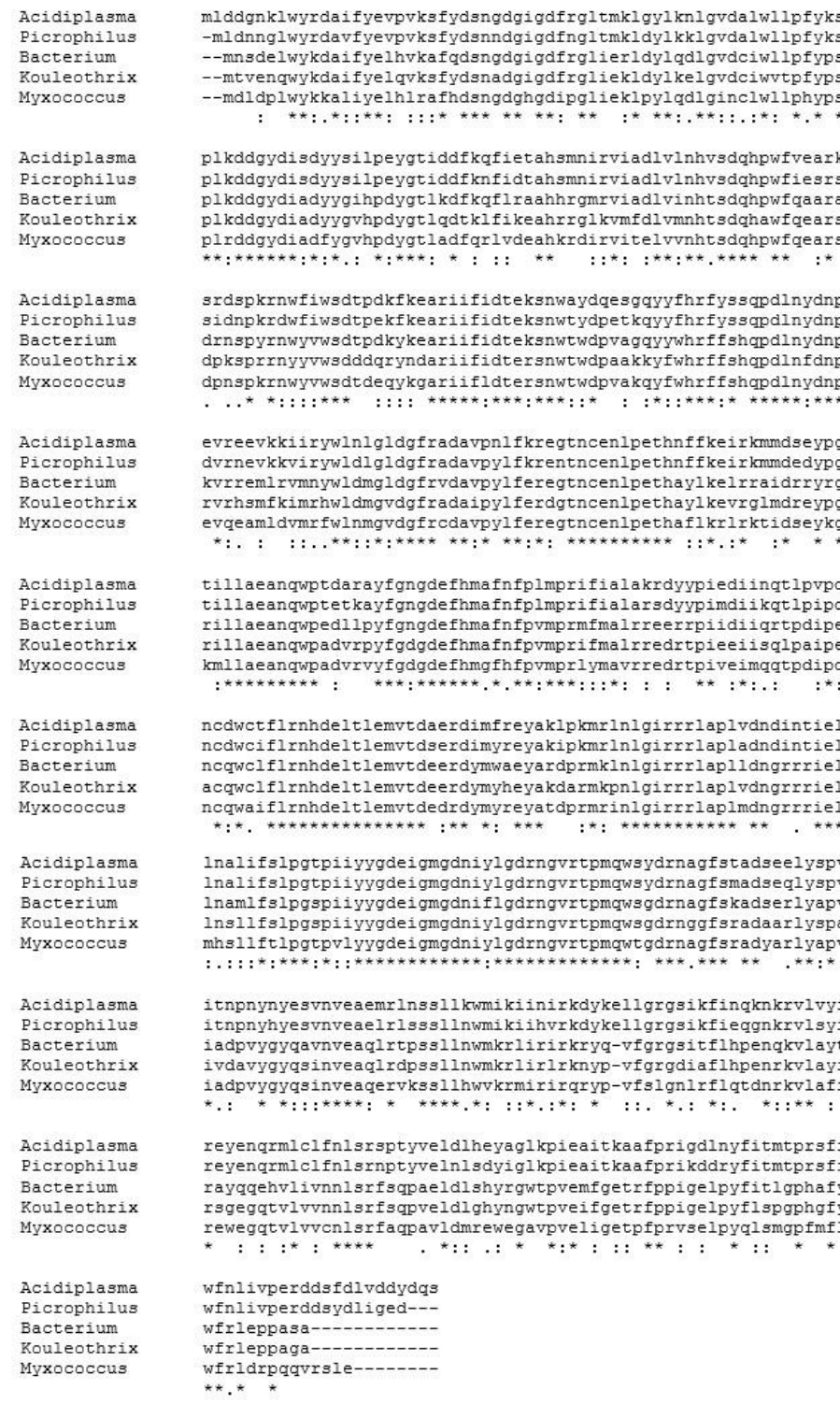

Figure 1 Acidiplasma $s p$ MBA-1 amino acid sequence comparison with Trehalose synthase from different organisms. The amino acids marked by asterisks are sequence identical in all sequences. Amico acid marked by colons and dots are strongly and weakly conserved, respectively

\section{SDS Page}

TreS gene encodes a polypeptide of 562 residues with a calculated molecular mass of $66.09 \mathrm{kDa}$. Target recombinant protein purification was carried out using 
nickel affinity column chromatography. SDS-PAGE analysis gave a strong protein band with a molecular mass of $65.9 \mathrm{kDa}$. The specific activity of this protein was $3.568 \mathrm{Umg}^{-p^{2} \mathrm{ptein}^{-1}}$ in the purified enzyme.

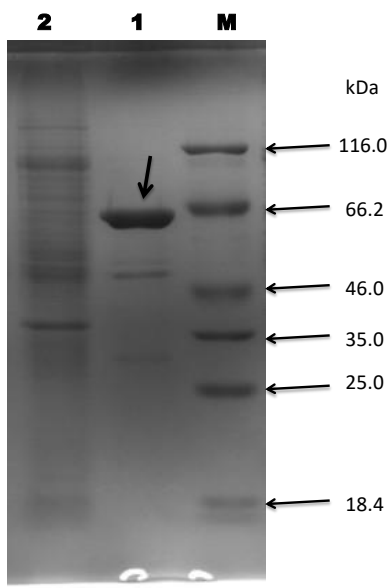

Figure 2 SDS-PAGE analysis of the recombinant protein. Lane 1 purified recombinant Tres (arrow indicates purified enzyme) Lane 2 Crude extract of the recombinant TreS. Lane M Molecular weight standards (116.0, 66.2, 46.0, 35.0, $25.0,18.4 \mathrm{kDa})$

\section{Effect of pH on recombinant TreS}

Figure 3. shows the effect of $\mathrm{pH}$ on recombinant TreS activity. TreS showed the highest relative activity at $\mathrm{pH} 6.5$ whereas the relative activity was $91.35 \%$ and $53.28 \%$ at $\mathrm{pH} 7.0$ and 7.5 , respectively. At higher $\mathrm{pH}$ value the activity of TreS dropped sharply.

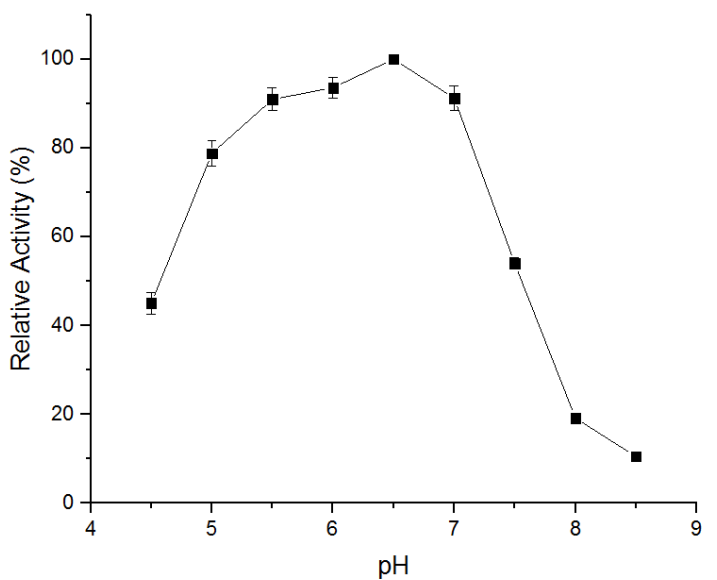

Figure 3 Effect of $\mathrm{pH}$ on recombinant TreS activity. Values are the means of three replicates \pm standard deviation.

\section{Effect of Temperature on recombinant TreS}

As shown in figure 4 , the enzyme showed maximum activity at a temperature of $40{ }^{\circ} \mathrm{C}$, whereas at 35,30 and $25{ }^{\circ} \mathrm{C}$ the relative activity decreased to $81.2 \%$, $69.7 \%$, and $42.4 \%$, respectively. The enzyme activity increased up to $40{ }^{\circ} \mathrm{C}$ and then gradually decreased. The activity was dropped to $9.3 \%$ at $60^{\circ} \mathrm{C}$.

The thermal stability of the enzyme was examined at pH 6.5 in a standard buffe (50mM Sodium phosphate buffer). As shown in figure 4, the relative activity of the enzyme was almost constant up to $40^{\circ} \mathrm{C}$ and the relative activity dropped significantly to $90,71,22$ and $0 \%$ after incubation for $1 \mathrm{~h}$ at $45,50,55$ and $60{ }^{\circ} \mathrm{C}$, respectively.

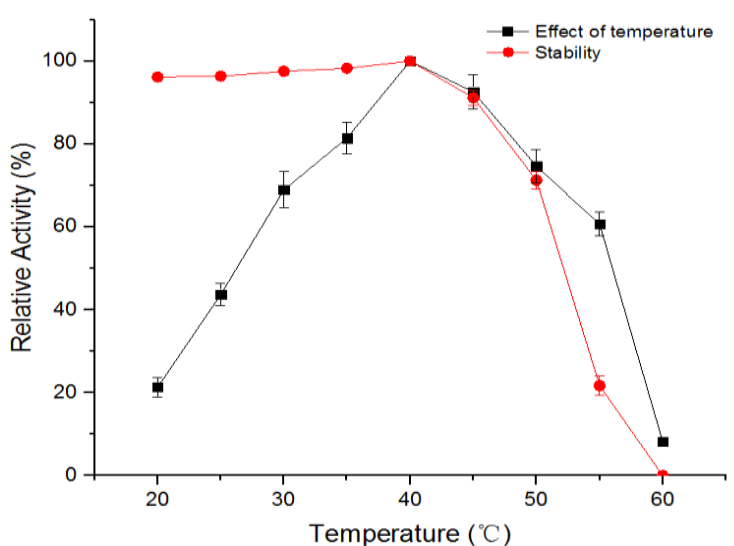

Figure 4 Effect of temperature on recombinant TreS activity. (ロ) effect of temperature on the enzyme activity ( $\bullet$ ( effect of temperature on the enzyme stability. To examine the thermal stability of TreS, the enzymes were preincubated at various temperatures $\left(20-60{ }^{\circ} \mathrm{C}\right)$ for $1 \mathrm{~h}$ at $\mathrm{pH}$ 6.5. The residual activities were measured at $40{ }^{\circ} \mathrm{C}$. Values are the means of three replicates \pm standard deviation.

\section{Effect of metal ions on recombinant TreS}

The recombinant TreS was assayed in the presence of various metal ions, which were incubated with an enzyme solution at a final concentration of $1 \mathrm{mM}$. The enzyme assay showed that magnesium, EDTA and Lithium raised the enzyme activity by $10.9 \%, 9.6 \%$, and $6.7 \%$ respectively. Enzyme activity did not significantly change when incubated with manganese. The enzyme activity decreased significantly when incubated with cobalt, zinc, and nickel to $62.5 \%$, $41.8 \%$, and $33.34 \%$, respectively, whereas copper completely inhibited the TreS enzyme activity.

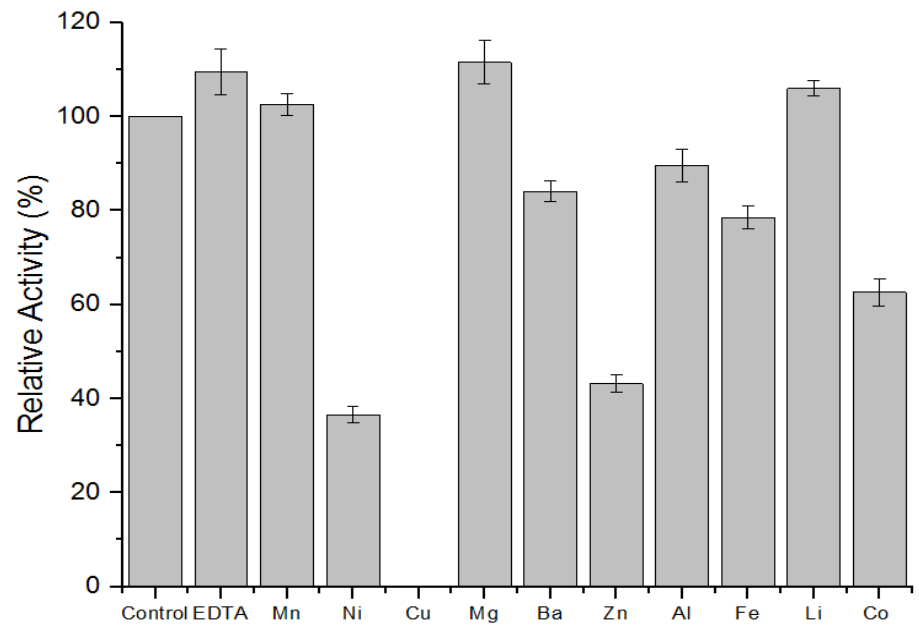

Figure 5 Effect of metal ions on recombinant Tres activity. Values are the means of three replicates \pm standard deviation.

\section{Substrate Specificity}

Only maltose showed substrate specificity with TreS. The other substrates (Glucose, Lactose, Sucrose, Fructose, Mannose, $\beta$-cyclodextrin, Starch, Cellobiose and Galactose) showed no specificity (data not shown) for TreS as they did not produce any trehalose in the reaction.

\section{Table 1 Substrate Specificity for TreS}

\begin{tabular}{ll}
\hline Substrate & Trehalose $^{*}$ \\
Glucose & $\times$ \\
Lactose & $\times$ \\
Sucrose & $\times$ \\
Fructose & $\times$ \\
Maltose & $\sqrt{ }$ \\
Mannose & $\times$ \\
Starch & $\times$ \\
Cellobiose & $\times$ \\
Galactose & $\times$ \\
$\beta$-cyclodextrin & $\times$ \\
\hline
\end{tabular}




\section{Conversion profile}

The purified enzyme ) $100 \mu \mathrm{l}$ ( was incubated in $900 \mu$ lsodium phosphate $(50 \mathrm{mM})$ buffer $(\mathrm{pH} 6.5)$ at $40{ }^{\circ} \mathrm{C}$ for $0-10 \mathrm{~h}$, using $1 \%$ maltose as a substrate. All the reactions were stopped by boiling them for $10 \mathrm{~min}$ before the samples were analyzed by the HPLC system. After $9 \mathrm{~h}$ of reaction, the conversion rate of trehalose and glucose were $43.62 \%$, and $22.01 \%$ respectively.

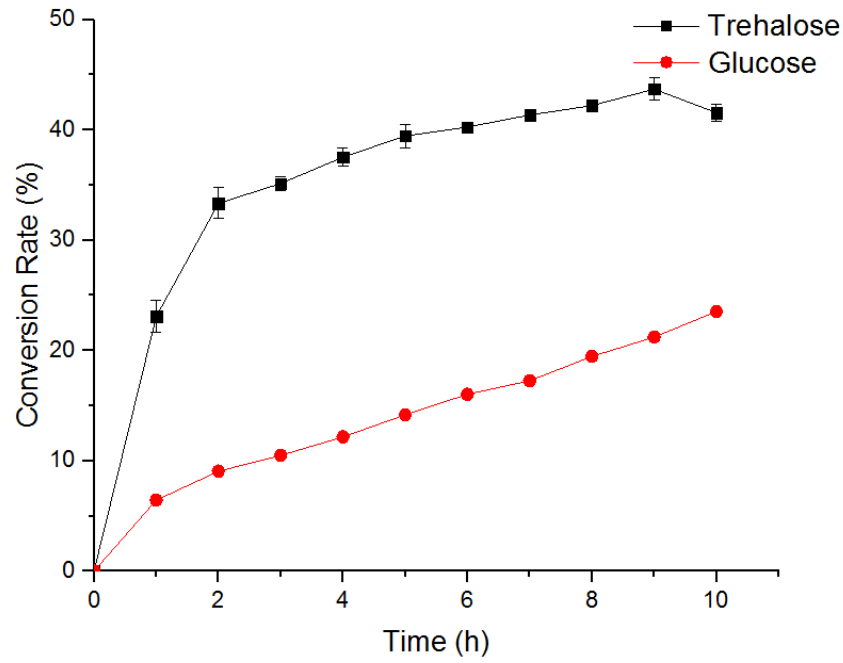

Figure 6 Conversion rate of trehalose and glucose from maltose with a different time (0-10h)

\section{DISCUSSION}

We have confirmed that the gene (gi= 765468230) from Acidiplasma sp. MBA-1. encoded a functional enzyme, trehalose synthase, and it could catalyze the conversion of maltose to trehalose. The optimum temperature of TreS found 40 ${ }^{\circ} \mathrm{C}$ which similar to those trehalose synthases coming from Actinoplanes SN223/29)Lee et al., 2008). TreS maintained a high relative activity up to $45^{\circ} \mathrm{C}$ while checking the stability of the enzyme against temperature. The optimum $\mathrm{pH}$ was 6.5, similar to several trehalose synthases reported in past studies (Liang $\boldsymbol{e}$ al., 2013; Wu et al., 2009). TreS activity was increased by $\mathrm{Mg}^{2+}$ and $\mathrm{Li}^{+}$. The trehalose synthase from Pseudomonas sp (Gao et al., 2013), Deinococcus sp. )Jiang et al., 2013(, Deinococcus radiodurans )Filipkowski et al., 2012( is also reported to increase their activity by $\mathrm{Mg}^{2+}$. EDTA has slightly enhanced the activity of the enzyme. We have not found any obvious reasons for that It is most likely, EDTA is chelating metal ions that affect that binding site of TreS. TreS activity was strongly inhibited by $\mathrm{Cu}^{2+}$. It is probably because copper ions were interfering with the binding site of TreS and making it inactive in the reaction. Other studies are also suggesting the same (Yan et al., 2013; Zhu et al., 2010). Our experimental data showed that TreS could convert about $43.62 \%$ maltose to trehalose, accompanied by about $23.85 \%$ glucose as a byproduct afte $10 \mathrm{~h}$ of incubation. Other studies suggest that most TreS enzyme could produce glucose as a by product except Pseudomonas stutzeri CJ38 (Lee et al., 2005). It is reported that glucose normally can inhibit the enzyme activity (Chen $\boldsymbol{e t}$ al 2006) and lowers the conversion rate from maltose to trehalose (Wei et al. 2004). Several other studies suggest that the trehalose synthases that produce less or no glucose as a byproduct have a higher production for trehalose of about $70 \%$ to 80\% (Lee et al. 2005; Chen et al., 2006; Nishimoto et al., 1995,Nishimoto et al., 1996). As TreS possess a weak hydrolytic activity (Zhu et al., 2010), it could be the reason as to why a high amount of glucose is produced. TreS could produce trehalose from maltose with a single step. Maltose is relatively cheap and this pathway could be an alternative method for industrial trehalose production. A number of Trehalose Synthase enzymes from different bacterial strains (Nishimoto et al., 1995; Nishimoto et al., 1996 ; Chen et al., 2006; Zdzieblo and Synowiecki, 2006; Wei et al., 2004; Gao et al., 2013; Yan et al., 2013; Jiang et al., 2013; Liang et al., 2013; Filipkowski et al., 2013( have been identified and characterized. This study provided the characteristics of trehalose synthase from Acidiplasma sp. MBA-1 for the trehalose catalysis metabolism.

\section{CONCLUSION}

In our experiment, enzyme TreS produced from Acidiplasma spMBA-1 can catalyze a considerable amount of maltose into trehalose in a single step reaction. We know that maltose is a relatively cheap substrate. Hence, TreS could be used as an alternative commercial enzyme to produce trehalose commercially. There is a drawback though. A significant amount of glucose is being produced as a byproduct which hinders the production of commercial trehalose. If it is possible to suppress glucose production by genetic modifications, it could enhance trehalose production. Beside, enzyme immobilization technique can be used to improve trehalose production further.

\section{REFERENCE}

Aga H, Shibuya T, ChaenH, Fukuda S, Kurimoto M. 1998. 'Stabilization by trehalose of superoxide dismutaselike activity of various vegetables'. NipponShokuhin Kagaku Ko- gakuKaishi 45(3):210-215 https://dx.doi.org/10.3136/nskkk.45.210

Argüelles JC: 'Physiological roles of trehalose in bacteria and yeast: a comparative analysis'. Arch Microbiol 2000, 174:217-224. https://doi.org/10.1007/s002030000192

Avonce N, Mendoza-Vargas A, Morett E, Iturriaga G. 'Insights on the evolution of trehalosebiosynthesis'. BMC Evolutionary Biology. 2006;6:109. https://dx.doi.org/10.1186/1471-2148-6-109

Bradford. M.M, 1976, 'Rapid and sensitive method for the quantification of microgram quantities of protein utilizing the principle of protein dye binding ', Anal. Biochem. 72: 248-254.https://dx.doi.org/10.1016/0003-2697(76)90527-3

Chen YS, Lee GC, Shaw JF (2006) Gene cloning, expression, and biochemica characterization of a recombinant trehalose synthase from Picrophilus torridus inEscherichia coli. J Agric Food Chem 54: 7098-7104. https://dx.doi.org/10.1021/jf060828q

Colaco CALS, Roser B. 1995. Trehalose-A multifunctional additive for food preservation. In Food packaging and preservation; Mathlouthi M, Ed. London: Blackie Professional, pp 123-140. https://dx.doi.org/10.1007/978-1-4615 2173-0

Di Lernia, I., Morana, A., Ottombrino, A., Fusco, S., Rossi, M., \& De Rosa, M (1998). Enzymes from Sulfolobusshibatae for the production of trehalose and $\begin{array}{llll}\text { glucose from } & \text { starch. } & \text { Extremophiles, } & 2,\end{array}$ 416.https://dx.doi.org/10.1007/s007920050086

Elbein AD, Pan YT, Pastuazak I \& Carroll D 2003, 'New insights on trehalose: a multifunctional molecule', Glycobiology, vol. 13, no. 4, pp. 17 27.https://dx.doi.org/10.1093/glycob/cwg047

Elbein AD. 1974. The metabolism of alpha,alpha-trehalose AdvCarbohydrChemBiochem 30:227-256.https://dx.doi.org/10.1016/S0065 2318(08)60266-8

Filipkowski P, Pietrow O, Panek A, Synowiecki J (2012) Properties of recombinant trehalose synthase from Deinococcus radiodurans expressed in Escherichia coli. ActaBiochim Pol 59: 425-431.PMID:23032750

Gao Y $, \underline{\text { Xi Y }}, \underline{\mathrm{Lu} \text { XL, Zheng H}}, \underline{\mathrm{Hu} \quad \mathrm{B}}, \underline{\text { Liu XY }}$, Jiao BH .2013 , Cloning expressionand functional characterization of anovel trehalose synthase from marine Pseudomonas sp. P8005World J Microbiol Biotechnol ., 29(11):2195 206.https://dx.doi.org/10.1007/s11274-013-1385-2

Higashiyama T. 2002. Novel functions and applications of trehalose. Pure ApplChem 74(7):1263-1269. https://doi.org/10.1351/pac200274071263

Himei S. 2008. 'New developments in the use of Treha(R) in the food industry'. Food Chem, 7:25-29.

Jain NK,Roy I. 2009. Effect of trehalose on protein structure. Protein Sci 18(1):24-36. https://doi.org/10.1002/pro.3 Jiang L, Lin M, Zhang Y, Li Y, Xu X, Li S, et al. (2013) Identification and Characterization of a Novel Trehalose Synthase Gene Derived from Saline-Alkali Soil Metagenomes. PLoS ONE 8(10): e77437https://dx.doi.org/10.1371/journal.pone.0077437Kubota M. 2005. New features and properties of trehalose. New Food Industry 47(3):17-29.

Lama, I., Nicolaus, B., Trincone, A., Morzillo, P., De Rosa, M., \&Gambacorta, A. (1990). 'Starch conversion with immobilized thermophilicarchaea bacterium SulfolobusSolfataricus. Biotechnology Letters, 12, 431-

432.https://dx.doi.org/10.1007/BF01024398

Lee JH, Lee KH, Kim CG, Lee SY, Kim GJ et al. (2005) Cloning and expression of a trehalose synthase from Pseudomonas stutzeri CJ38 in Escherichia coli for the production of trehalose. ApplMicrobiolBiotechnol 68: 213 219.https://dx.doi.org/10.1007/s00253-004-1862-5

Lee, J. S., Hai, T., Pape, H., Kim, T. J., \&Suh, J. W. (2008). Three trehalose synthetic pathways in the acarbose-producing Actinoplanessp. SN223/29 and evidence for the TreY role in biosynthesis of component C. Applied Microbiology and Biotechnology, 80(5), 778.https://dx.doi.org/10.1007/s00253-008-1582-3

Liang JY, Huang RB, Huang Y, Wang XB, Du LQ et al. (2013) Cloning, expression, properties, and functional amino acid residues of new trehalose synthase fromThermomonospora curvata DSM 43183.Journal of Molecular Catalysis B: Enzymatic.Vol. 90, pp 26-32._https://dx.doi.org/ 10.1016/j.molcatb.2013.01.014

Mizumoto T, Masuda Y, KajiyamaA,Yanagisawa M, Nyshad- ham JR. 2004 Quick disintegrating tablet in buccal cavity and production process thereof Patent Application US10/ 961,875.

Nakada, T., Ikegami, S., Chaen, H., Kubota, M., Fukuda, S., Sugimoto, T, Kurimoto. M and Tsujisaka. Y, (1996), 'Purification and characterization of thermostable maltooligysyltrehalose synthase from the thermo-acidophilic archeabacterium sulfolobus acidocaldarius.'Bioscience Biotechnology and Biochemistry. 60: 263-266. https://dx.doi.org/10.1271/bbb.60.263 
Nakada, T., Ikegami, S., Chaen, H., Kubota, M., Fukuda, S., Sugimoto, T, Kurimoto. M and Tsujisaka. Y, (1996), 'Purification and characterization of thermostablemaltooligysyltrehalosetrehalohydrolase from the thermo-acidophilic archeabacterium sulfolobusacidocaldarius.' Bioscience Biotechnology and Biochemistry. 60 (2): 267-70. https://dx.doi.org/10.1271/bbb.60.267

Nishimoto T, Nakada T, Chaen H, Fukuda S, Sugimoto T, Kurimoto M, Tsujisaka Y (1996) Purification and characterization of a thermostabletrehalose synthase from Thermusaquaticus. Biosci Biotech Biochem60)5(:835- .839 https://dx.doi.org/10.1271/bbb.60.835

Nishimoto. T, Nakano. M, Nakada. T, Chaen. H, Fukuda. S, Fukuda. S, Sugimoto. T, Kurimoto. M, and Tsujisaka. Y, 1995, 'Purification and properties of a novel enzyme, trehalose synthase, from pimelobacter sp.
R48.',BiosciBiotechnolBiochem.
60 (4)
$640-$

4.https://dx.doi.org/10.1271/bbb.60.640

Oku K, Chaen H, Fukuda S, Kurimoto M. 1999. Effect of trehalose on suppression of trimethylamine-formation from boiling fish meat. Nippon Shokuhin Kagaku KogakuKaishi 46(5):319322. https://dx.doi.org/10.3136/nskkk.46.319

Oku K,ChaenH, Fukuda K, Kurimoto M. 1999. 'Suppression of the formation of foul odor by trehalose'. Collection from The Second Trehalose Symposium:6571.

Richards AB, Dexter LB, in Alternative Sweeteners (Ed.L.O. Nabors), Marcel Dekker, Inc.: New YorkNY. 2001, pp 423-461.

Richards AB, Krakowka S, Dexter LB, Schmid H, Wolterbeek APM, WaalkensBerendsen DH, Shigoyuki A, Kurimoto M: Trehalose: a review of properties, history of use and human tolerance, and results of multiple safety studies. Food ChemToxicol 2002, 40:871-898.https://dx.doi.org/10.1016/S0278 $\underline{6915(02) 00011-X}$

Schiraldi, C., Di Lernia, I., \& De Rosa, M. (2002). Trehalose production: exploiting novel approaches. Trends in Biotechnology, 20, 420 425.https://dx.doi.org/10.1016/S0167-7799(02)02041-3

Wei YT, Zhu QX, Luo ZF, Lu FS, Chen FZ et al. (2004) Cloning, expression and identification of a new trehalose synthase gene from Thermobifida fusca genome. ActaBiochimBiophys Sin 36: 477-484.https://dx.doi.org/10.1093/abbs/36.7.477

Wu XL, Ding HB, Yue M, Qiao Y (2009) Gene cloning, expression, and characterization of a novel trehalose synthase from Arthrobacter aurescens ApplMicrobiolBiotechnol 83: 477-482.https://dx.doi.org/10.1007/s00253-009$\underline{1863-5}$

Yan J, Qiao Y, Hu J, and Ding H, 2013, 'Cloning, expression and characterization of a trehalose synthase gene from a Rhodococcusopacus', The Protein Journal, vol. 32, no. 3, 223-9. https://dx.doi.org/10.1007/s10930-0139476-3

Zdzieblo. A \&Synowiecki. J, 2006, 'Production of trehalose by intramoleculartransglucosylation of maltose catalysed by a new enzyme from HB-8 '.Food Chemistry, vol. 96. no. 1. pp 8-13 https://dx.doi.org/10.1016/j.foodchem.2005.01.048

Zhu, Y., Wei, D., Zhang, J., Wang, Y., Xu, H., Xing, L., \& Li, M. (2010) Overexpression and characterization of a thermostabletrehalose synthase from Meiothermusruber. Extremophiles, 14(1),

8.https://dx.doi.org/10.1007/s00792-009-0281-z 